\title{
Development of baked snack with fats and proteins powder mixtures as a fresh cheese substitute
}

\author{
Fabiana FUENTES-ARISMENDY ${ }^{1}$, Eduardo RODRIGUEZ-SANDOVAL ${ }^{1 \star}$ (D), Alejandro MEJIA-VILLOTA ${ }^{2}$, \\ Tatiana VELEZ-URIBE², Víctor HERNANDEZ ${ }^{2}$
}

\begin{abstract}
The objective of this study was to evaluate powder mixtures as substitutes of fresh cheese in traditional manufacturing of a baked snack, due to the cheese variability in its quality properties and its high cost. In the cheese substitute powder mixtures, protein was varied with sodium caseinate/whey protein ratios in ranges from 7.33 to 13.29 and the fat with lecithin/microencapsulated vegetable fat (MVF) ratios from 1.5 to 4 . The optimal formulation according to the textural properties was the one composed of sodium caseinate/whey protein ratio of 7.84 and lecithin/MVF ratio of 4 . The optimum was compared with a snack control sample prepared in a traditional way using fresh cheese and its porosity, specific volume, texture, microstructure, composition and sensory characteristics were measured, as well as the texture during 30 days of storage. Significant differences were found regarding porosity, specific volume and microstructure. During storage the hardness of both samples increased; however, the control always showed less resistance to cutting and puncture. Snacks made with the powder mixture had higher protein content and less fat; however, its sensory acceptance by consumers was lower compared to traditional samples.
\end{abstract}

Keywords: baked snack; cheese; protein; fat; microstructure.

Practical Application: Snack with powdered fats and proteins had higher protein and lower fat than a traditional snack.

\section{Introduction}

Snacks are mainly defined as those foods occasionally eaten between meals. However, a generalized concept has not been accepted due to the different varieties existing the market (Johnson \& Anderson, 2010; Hess \& Slavin, 2018). Worldwide, the consumption of snacks has increased in recent years, which has led to studies that analyze their impact on the diet, improve their production, and evaluate the quality of the product (Ovaskainen et al., 2006; Paula \& Conti-Silva, 2014; Kahlon et al., 2017). Ring-shaped baked snacks are a type of a snack traditionally made with cassava starch, cheese, yeast, and egg. At compositional level it is low fat, does not contain sugar, and it is gluten free, which makes it attractive to consumers in addition to its characteristic flavor and crispy texture. Properties such as color, shape, texture, and size in bakery products are greatly affected by the ingredients used and the processing method (Jiang et al., 2019).

In these baked snacks, the bases of the formulation are cassava starch and costeño cheese. Cassava starch is preferred in the food industry because, as ingredient, it provides a smooth taste and pure white color to products (Moorthy et al., 2018). In fact, its worldwide production reaches high levels with up to 3 - 4 million tons per year (Tran et al., 2015; Díaz et al., 2019). On the other hand, the costeño cheese has a high fat content, dry consistency, salty flavor (characteristic), and a creamy or white color. In bakery products in which it is used as an ingredient, it contributes to the texture, taste, and mouthfeel. Costeño cheese in Colombia is made in industrial and craft way, the latter uses raw milk for production and has no control of the variables that can affect the process (Serpa et al., 2016). There is also a deficiency in good manufacturing practices (GMP), occasionally resulting in products containing total coliforms, fecal coliforms, Listeria spp., Salmonella spp., and some fungi (Mesa et al., 2019; Tadjine et al., 2020). In the industrial production of costeño cheese, pasteurized milk is used, conditions are improved, and the microbiological load is adjusted to the permitted levels; however, the sensory quality and physicochemical properties of the cheese are affected (Serpa et al., 2016). Regardless the way in which the cheese is produced, it is still a fresh product with high moisture content and a short shelf-life, which requires chilling to keep it in a good condition and increases its cost as raw material in the industrial process (Quisca et al., 2019). The industry demands between 25 and 35 tons of cheese per month. Furthermore, the texture and sensory properties between batches of costeño cheese from the same producer are not homogeneous, which not only affects the quality and standardization of the final product it is added to, but also causes differences in the product formulation for each batch.

One of the alternatives to overcome the challenges described is to develop imitation cheeses. Imitation or analogue cheeses are products obtained from the mixture of proteins, fats/oils, 
and emulsifying salts, among others, in order to achieve a matrix similar to that of cheese, either for direct consumption or as an ingredient of a processed product. This type of cheese offers a great advantage by allowing the formulations to be modified in such a way as to achieve desired levels in parameters such as texture, flavor, flowability, stretchability, or expansion (Masotti et al., 2018). Arimi et al. (2008) studied different formulations to make an expanded imitation cheese heated in microwave, in which the fat percentage was reduced by making substitutions with resistant starch, and concluded that fat-free cheeses had a greater expansion and therefore result in a crispier product.

Despite the research presented above, there are still no reports on the application of a powdered mixture to prepare a baked snack where fresh cheese is replaced. The objective of this study was to evaluate mixtures of powders as substitutes for fresh cheese in the production of ring-shaped baked snacks, so that their quality properties were similar to a traditionally prepared baked snack. This aims to improve the production, standardization, and traceability of the process, in addition to reducing costs by replacing fresh cheese.

\section{Materials and methods}

\subsection{Materials}

For the preparation of ring-shaped baked snacks, the powder mixture contained: sodium caseinate (Foodchem International Corporation, Shanghai, China), whey protein (Bell Chem International SAS, Medellin, Colombia), guar gum (Bell Chem International SAS, Medellín, Colombia), microencapsulated vegetable fat (MVF) (Betacream, ALSEC SAS, la Estrella, Colombia), soy lecithin (ALSEC SAS, la Estrella, Colombia), potassium sorbate (Bell Chem Internacional SAS, Medellín, Colombia), lactic acid (Bell Chem Internacional SAS, Medellin, Colombia), salt (Brinsa SA, Medellin, Colombia), sodium citrate (Tecnas, Itagui, Colombia), egg powder (Compañía Avícola SA, Santa Fe, Argentina), double acting baking powder (Colorisa SAS, Sabaneta, Colombia), modified cassava starch (Gel ${ }^{\circledR}$ Baking XP, Poltec SAS, La Estrella, Colombia), and water.

\subsection{Preliminary study}

The traditional formulation for the preparation of ring-shaped baked snacks consists of cassava starch, costeño cheese, yeast, fresh egg, and water. Therefore, baking powder and egg powder were used as substitutes for yeast and fresh egg, respectively, in order to obtain a similar product. Subsequently, the formulations reported in the literature were followed to replace the cheese, using the ingredients available in the market and modifying the original formulations (Arimi et al., 2008; Kiziloz et al., 2009; Hosseini et al., 2014). Three types of fats or emulsifiers and three types of protein were tested in different percentages to establish a formulation able to provide the best properties. Margarine, lecithin, and microencapsulated vegetable fat (MVF) were the fat sources applied alone or in combination with each other. Similarly, sodium caseinate, calcium caseinate, and whey protein were added as protein components, either alone or in different combinations. The fat and protein percentage presenting the best results was determined from different trials. In addition, the most suitable combinations between fats and proteins that resulted in a better shape and expansion of the ring-shaped baked snacks were chosen.

\subsection{Sample preparation}

For preparing ring-shaped baked snacks from the powder mixture, the ingredients were the following: $100 \mathrm{~g}$ of modified cassava starch, $104 \mathrm{~g}$ of tap water, $2.6 \mathrm{~g}$ of egg powder, $2 \mathrm{~g}$ of guar gum, $8.2 \mathrm{~g}$ of additives and mineral salts, $24 \mathrm{~g}$ of protein and $28 \mathrm{~g}$ of fat. The amount of protein was varied in a sodium caseinate/whey protein ratio from $7.33 / 1$ to $13.29 / 1$, and the amount of fat in a lecithin/MVF ratio from $1.25 / 1$ to $4 / 1$. The treatments were reported as $C$ to identify the sodium caseinate/whey protein ratio, and $\mathrm{L}$ to name the lecithin/ MVF ratio, both letters followed by the percentage value of the numerator. For instance, C91L73 represents a sample containing $91 \%$ caseinate- $9 \%$ whey protein and $73 \%$ lecithin-27\% MVF for protein and fat, respectively. All the ingredients were mixed to form a dough, then, samples of about $5 \mathrm{~g}$ were taken and molded in a characteristic ring-shape. For the baking process, a convection oven (GFO-4B, Guangzhou Youjia Machinery Co., China) was initially operated at $170{ }^{\circ} \mathrm{C}$ for $10 \mathrm{~min}$ and then at $150{ }^{\circ} \mathrm{C}$ for $28 \mathrm{~min}$.

In order to compare to the control, ring-shaped baked snacks were prepared in a traditional way with the following formulation: $100 \mathrm{~g}$ of modified cassava starch, $100 \mathrm{~g}$ of costeño cheese (Quesitos Maya Ltda, Medellin, Colombia), $10 \mathrm{~g}$ of fresh egg, $2 \mathrm{~g}$ of instant yeast (Fermipan, Lesaffre Colombia Ltda, Cali, Colombia), and $63 \mathrm{~g}$ of water. All the ingredients, except water, were blended until a homogeneous mixture was obtained. Water was then added in small quantities $(10 \mathrm{~mL})$ until an adequate consistency was reached. The dough was introduced into a proofing cabinet (model KL 864-HT, EKA, Padova, Italy) at $40{ }^{\circ} \mathrm{C}$ for $20 \mathrm{~min}$ with a relative humidity above $80 \%$. Then, the dough was divided into samples of about $5 \mathrm{~g}$ and molded into a ring-shape, it was allowed to rest again in a proofing cabinet for $30 \mathrm{~min}$ with the same conditions described previously. During baking, an initial temperature of $215^{\circ} \mathrm{C}$ in the upper part and $210^{\circ} \mathrm{C}$ in the lower part was used for $6 \mathrm{~min}$, and then, both temperatures were lowered to $150^{\circ} \mathrm{C}$ for $16 \mathrm{~min}$.

\subsection{Analytical methods}

The moisture percentage was determined with a $2 \mathrm{~g}$ sample using the AOAC method 945.15 (Association of Official Analytical Chemists, 2005). The methodology developed by Arimi et al. (2008) was followed to determine weight loss and 5 samples were analyzed for all treatments. The specific volume was evaluated (Mudgil et al., 2016). The porosity of the ringshaped baked snacks was calculated using the equation proposed by Özer et al. (2004), five samples were measured to report the results. The texture of the ring-shaped baked snacks was analyzed by a texture analyzer (TA-XT2i, Stable Micro Systems, Godalming, U.K.) using a $50 \mathrm{~kg}$ load cell. A Warner-Bratzler shear blade with guillotine probe was used to determine the 
product hardness making a cut perpendicular to the main axis of the sample until complete breaking. The needle probe was used to establish the hardness in the crust until half of the sample was perforated. For both tests, a speed of $1 \mathrm{~mm} / \mathrm{s}$ was used for the test and $3 \mathrm{~mm} / \mathrm{s}$ for the pre- and post-test speed (Paula \& Conti-Silva, 2014); 10 samples were analyzed for each treatment.

\subsection{Storage evaluation}

For the assessment during storage two treatments were evaluated; a control sample produced in a traditional way and the best sample in quality characteristics corresponding to the statistical evaluation of the tests carried out previously with the powdered materials (optimal condition). Samples were stored in polyethylene bags at room temperature for 30 days, texture was measured as previously described on storage days $1,5,10,15$, and 30 . The microstructure and composition of these two treatments were analyzed before beginning the storage tests. For SEM tests, fat was extracted by the soxhlet method, freeze dried (Labconco Freezone 12 Freeze Dryer, USA) with 2 heating increase steps from $-40{ }^{\circ} \mathrm{C}$ to $0{ }^{\circ} \mathrm{C}$ at a rate of $0.03{ }^{\circ} \mathrm{C} / \mathrm{min}$, kept for $1 \mathrm{~h}$, and then, they were brought to $30^{\circ} \mathrm{C}$ at a speed of $0.03{ }^{\circ} \mathrm{C} / \mathrm{min}$. Subsequently, samples were coated with a $5 \mathrm{~nm}$ gold layer (Quorum, Q150R ES, U.K). The microstructure was examined in a scanning electron microscope (ZEISS EVO ${ }^{\circledR}$ MA 10, Jena, Germany) using an acceleration voltage of $15 \mathrm{kV}$ (Oginni et al., 2015). Additionally, the composition was performed by the Association of Official Analytical Chemists (2005) as follows: Protein content using method No. 992.23 and fat using method No. 945.16.

Regarding the sensory evaluation, general acceptance, taste, and texture tests were performed on day 15 and 30 with a 10-point linear scale (Pimentel et al., 2016). The panel was made up of 100 randomly chosen people, 51 men and 49 women with an age range between 18 and 71 years old for day 15 . For day 30, a sample of 100 people with equal numbers of men and women was also analyzed but with an age range from 17 to 60 years old. The samples of each treatment were presented in random order to the panelists, and they were asked to rate their perception regarding taste, texture, and acceptability in general on a scale from 0 to 10 , where 0 is "I dislike it a lot" and 10 "I like it much". Moreover, a quantitative descriptive analysis (QDA) was carried out considering the following descriptors: Appearance (degree of surface uniformity, degree of irregularities and curving and perception of how cylindrical and straight the shape is) characteristic color (perception of an overall surface color), characteristic smell, characteristic flavor (perception of the flavor associated with ingredients flavor), crispiness (sudden, clean fracture/snap, louder and high-pitched noise, more brittle and easier to break down than crunchy foods. Sample breaks in a single stage), fracturability (ability to crumble when chewed), cohesiveness (degree of separation into crumbles), salty taste, and adhesiveness (degree to which the sample sticks to the mouth or teeth surface) (Instituto Colombiano de Normas Técnicas y Certificación, 1996; Philipp et al., 2017). The QDA was carried out with 10 semi-trained panelists ( 6 female, 4 male). Training sessions of 30 min were conducted over a period of 1 month to develop the terminology and describe the key sensory attributes of snack samples (Otero-Guzmán et al., 2020).

\subsection{Statistical analysis}

In this study, the response surface methodology (RSM) was used with a central composite design to determine the optimal formulation in the preparation of snacks with cheese replacement. From preliminary trials, the sodium caseinate/ whey protein ratio $\left(\mathrm{X}_{1}\right)$ and the lecithin/MVF ratio $\left(\mathrm{X}_{2}\right)$ were chosen as variables, as well as, their maximum and minimum values. Each parameter was coded with values of $-1.4,-1,0$, $1,1.4$ to identify the levels from the lowest to the highest, simplify the recording of the experimental conditions and data processing; the variables, ranges, and levels are shown in Table 1 . The design resulted in 16 experiments with 8 central points. The production order and studies of the treatments was carried out randomly to minimize the effects of variability due to external factors. The experimental design was organized with the help of Minitab ${ }^{\circledR} 18$ software (Minitab Inc. USA). The moisture content, the weight loss percentage, specific volume, porosity, and texture were evaluated as response variables. Furthermore, the traditionally prepared ring-shaped baked snacks and the resulting optimal condition were studied during storage by means of a one-way analysis of variance using the type of snack (control and optimum) as a factor. Results were analyzed in the $\mathrm{R}$ Studio software v1.2.1335 and the measurements were compared with the Tukey test with a significance level of 0.05 . Data were expressed as the mean \pm standard deviation.

\section{Results and discussion}

\subsection{Moisture content and weight loss}

The moisture content and its location within the food material are factors that significantly affect specific characteristics such as appearance, texture, and color, among others (RodriguezSandoval et al., 2015). The moisture content obtained from the treatments differs significantly with values from $4.58 \%$ to $8.27 \%$ (Table 2). The interactions between the protein and fat ratios did not significantly influence the values reported (data and contour plot not reported); however, a lower moisture content could be achieved at the intermediate points of the range, in which they were evaluated. Lower values of moisture content are desirable because this property is directly related to the product hardness (Mazumder et al., 2007; Oginni et al., 2015). Similarly, lower moisture content levels reduce the possibility of contamination by microorganisms since there is less water available (Fiorda et al., 2015). The weight loss is shown in Table 2

Table 1. Coded and real values of the experimental design variables.

\begin{tabular}{lcccccc}
\hline \multirow{2}{*}{ Variables } & Code & \multicolumn{5}{c}{ Ranges and levels } \\
\cline { 3 - 7 } & & -1.4 & -1 & 0 & 1 & 1.4 \\
\hline $\begin{array}{l}\text { Sodium Caseinate/ } \\
\text { Whey Protein }\end{array}$ & $\mathrm{X}_{1}$ & 7.33 & 8.21 & 10.31 & 12.41 & 13.29 \\
Lecithin/MVF & $\mathrm{X}_{2}$ & 1.5 & 1.87 & 2.75 & 3.63 & 4 \\
\hline${ }^{*}$ & & & & & &
\end{tabular}

${ }^{\star} \mathrm{MVF}$ : microencapsulated vegetable fat. 
Table 2. Properties of the ring-shaped baked snacks for each formulation depending on the sodium caseinate/whey protein ratio (X1) and the lecithin/MVF ratio (X2).

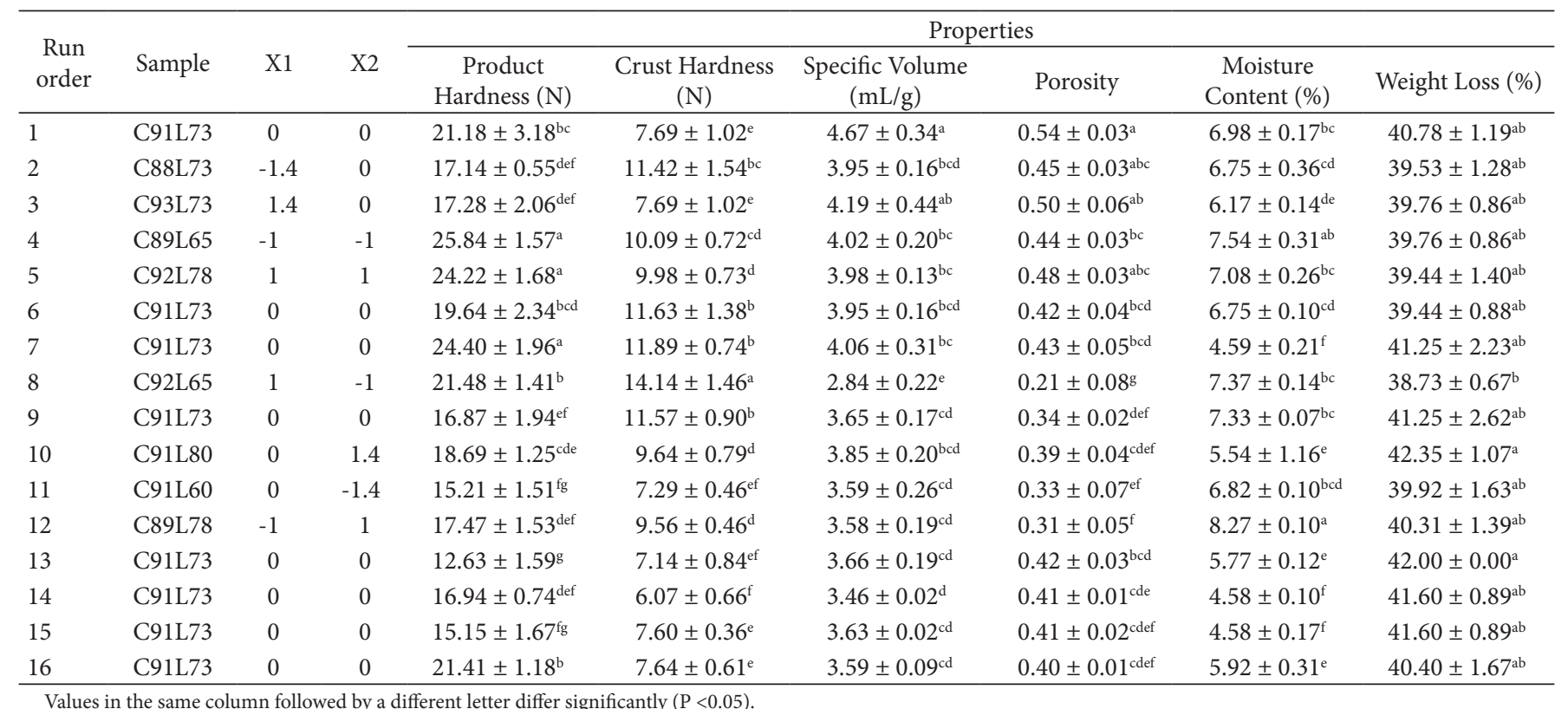

and ranged from $38.73 \%$ to $42.35 \%$. Weight loss focuses essentially on moisture content loss (Arimi et al., 2008) and it is evidenced by the values achieved in the treatment C91L80, where a higher percentage of weight loss (42.35\%) and low moisture content (5.54\%) were obtained.

\subsection{Specific volume, porosity, and texture}

The expansion of baked or fried foods is the result of the rapid increase in the molecular volume of water during evaporation, which leaves behind a porous internal structure (Saeleaw \& Schleining, 2011). Therefore, the amount and/or size of the pores is closely related to the expansion, microstructure, and consequently, contributes to the crispiness. Both specific volume and porosity are extremely important physical properties and determinants for the quality of products, whether baked, fried, or extruded (Lucas et al., 2018). A snack with maximum expansion and porosity is considered to be a positive quality that influences consumer acceptability.

The results of both specific volume and porosity are presented in Figure 1. The highest values for both specific volume and porosity were found with a lecithin/MVF (fat) ratio greater than 3 and casein/whey protein ratio (protein) greater than 12. This proportion of both fat and protein must be adjusted together and be inclusive in order to have the highest results. Arimi et al. (2008) found in their study on making a crispy imitation cheese that the reduction in the fat percentage induced further expansion. Numerous studies concluded that proteins affect the expansion and formation of pores because of their ability to influence the distribution of water within the product, since they tend to form denser structures and rigid networks that not only affect the increase in the product volume but also its hardness (Chaiyakul et al., 2009; Philipp et al., 2017). However, Arimi et al. (2012) reported that a snack with higher expansion was obtained by increasing the protein content, this was explained by stretching the hydrated protein matrix, which is swollen by the action of steam pressure while the product is in the oven or microwave. It should be noted that the results were far from the corresponding values, both for the commercial control (specific volume: $10.83 \mathrm{~mL} / \mathrm{g}$; porosity: 0.71 ) and the one prepared in the laboratory (specific volume: $6.19 \mathrm{~mL} / \mathrm{g}$, porosity: 0.56 ).

Texture and taste are the main factors that influence the palatability of food, especially in baked and extruded snacks (Chang \& Chen, 2013). Hardness is related to the force applied by the molar teeth to compress the food. The values are reported in Table 2 and are in a range of $12.63 \mathrm{~N}$ to $25.84 \mathrm{~N}$, similar to those found by Paula \& Conti-Silva (2014) with ring-shaped baked snacks made from cornmeal. In Figure le and 1f, it can be seen how the samples with casein/whey protein ratios of 10.5 to 13.29 and lecithin/MVF ratios lower than 2.4 have a lower hardness.

On the other hand, the crust hardness is related to breaking the food into pieces when biting using the incisors. The puncture test is widely used to characterize expanded products because the probe is expected to fracture the sample walls and, thus, give an indication of how hard the product is on the surface. The interactions between casein/whey protein ratios from 9 to 12 and lecithin/MVF ratios higher than 2.5 resulted in more brittle ring-shaped baked snack crusts (Figure $1 \mathrm{~g}$ and $1 \mathrm{~h}$ ). The protein amount influence on snack hardness was also reported by Philipp et al. (2017). Although 10 samples were analyzed for each formulation, a high level of variability was recorded in both properties evaluated within the replicates of the expanded products (Table 2). This could be attributed mainly to the lack of uniformity in expansion, which resulted in products with different structures (Arimi et al., 2008). 

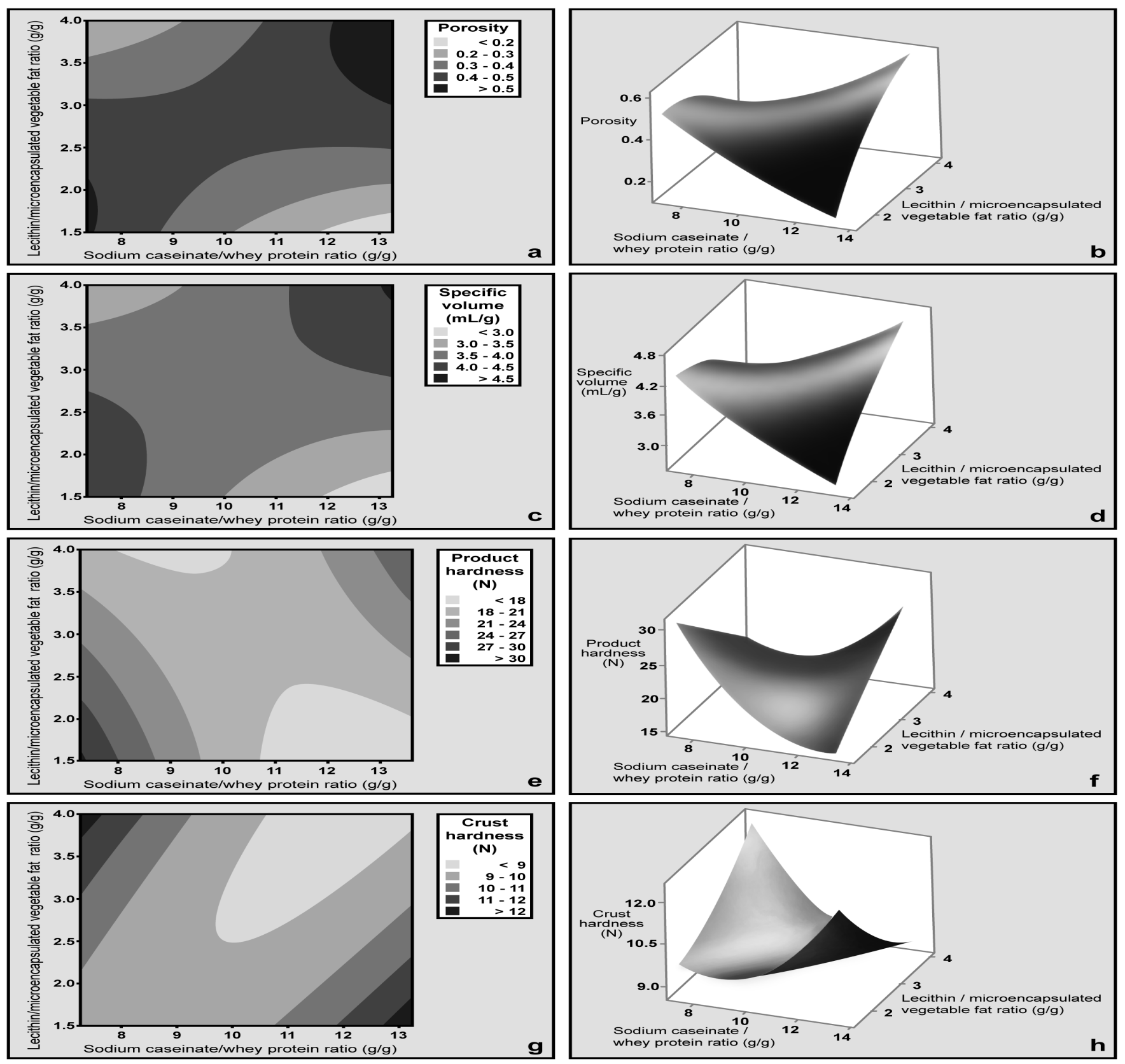

Figure 1. Porosity of the product contour (a) and response surface (b); and specific volume of the product contour (c) and response surface (d); hardness of the product contour (e) and response surface (f); and hardness of the crust contour ( $\mathrm{g}$ ) and response surface (h).

\subsection{Optimization}

In order to determine the optimum, properties such as specific volume, porosity, and texture were initially considered since they are very relevant sensory characteristics in the quality of the final product. However, the desirability values were low, mainly because the interactions between the protein and fat ratios had a different behavior for each property and the desirable ranges, for example, the samples that had the highest specific volume and porosity did not present the lowest product hardness, as evidenced in Figure 1. The specific volume and porosity of the control product were $10.83 \mathrm{~mL} / \mathrm{g}$ and 0.71 , respectively. These results differ significantly $(\mathrm{P}<0.05)$ from the ring-shaped baked snacks made from powder mixtures, whereas the texture results were closer, therefore, it was the parameter used to perform the optimization analysis.

A commercial type ring-shaped baked snack was chosen to establish the objective values for both the product hardness $(14.91 \mathrm{~N})$ and the crust hardness $(2.49 \mathrm{~N})$, giving $70 \%$ importance to the force exerted by the guillotine probe and $30 \%$ to the force exerted by the needle probe. According to the response surface method, the best ring-shaped baked snack was made with sodium caseinate/whey protein ratios of 7.84 and lecithin/MVF of 4 , resulting in a desirability of 0.8 . The 
program made a prediction of the values from this optimum that could result in: $14.91 \mathrm{~N}$ for product hardness and 8.56 $\mathrm{N}$ for crust hardness.

The ring-shaped baked snacks with the optimal formulation were characterized in their textural properties, specific volume and porosity, and then, they were compared to a sample produced in a traditional way (control). All optimal properties differ significantly $(\mathrm{P}<0.05)$ from the control sample. In terms of texture, the product developed showed a crust hardness $(6.23 \mathrm{~N})$ higher than those of the control samples $(4.97 \mathrm{~N})$; however, the value obtained was lower than that reported in the optimization for this property $(8.56 \mathrm{~N})$. For product hardness, values of $15.06 \mathrm{~N}$ for the control sample and $17.11 \mathrm{~N}$ for the optimum are presented. The porosity and specific volume of the control sample show values of 0.56 and $6.19 \mathrm{~mL} / \mathrm{g}$, respectively, while the optimal formulation presented 0.41 and $4.01 \mathrm{~mL} / \mathrm{g}$. In this case, the relationship between properties can be appreciated, for instance, by having a high porosity - and therefore a greater specific volume - a lesser force is necessary to fracture the samples, that is, higher porosity results in a higher degree of expansion and a crispy product is achieved, these being desirable characteristics for greater consumer acceptance of the snack. The differences appreciated between the types of samples are mainly attributed to the nature of the ingredients used and the manufacturing process, for example, the expansion occurs differently if yeast (control) or baking powder (optimal) is used.

\subsection{Scanning electron microscopy (SEM) and composition}

High resolution optical microscopy has become a suitable technique to evaluate the microstructure of materials (Sharma \& Bhardwaj, 2019). The control sample structure presents large pores, showing less thickness and small granules of starch on smooth surfaces (Figure $2 \mathrm{a}$ ). These images differ structurally from those presented in the studies conducted by Saeleaw \& Schleining (2011) and Oginni et al. (2015), because the process involved frying despite using cassava starch in their formulations; in those products, almost intact starch granules are easily and largely observed, while in this case (baked snacks), a few can be appreciated, perhaps because of the protein structure developed for both control and optimum conditions.
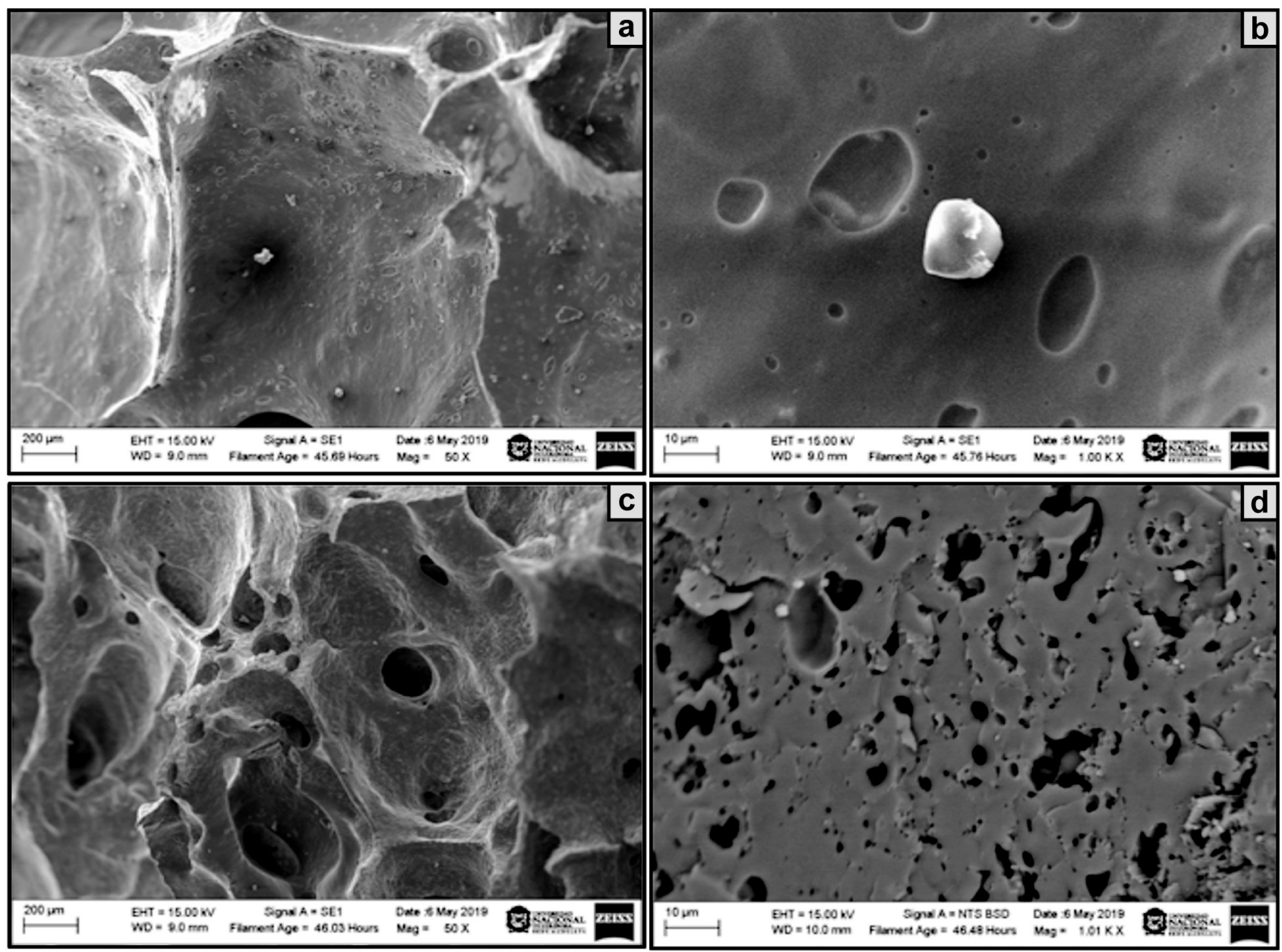

Figure 2. Micrographs of the control 50X (a) and 1000X (b) and optimum 50X (c) and 1000X (d). 
The structure of optimum sample was very different from the control as the pores observed are much smaller. The optimum samples present thick edges, and in general, a very rigid and compact structure can be seen (Figure $2 \mathrm{a}$ and $2 \mathrm{~b}$ ). This could explain the hardness of the product compared to the control. Such structure could be also attributed to the amount of protein used in the formulation (Chaiyakul et al., 2009; Philipp et al., 2017). The micrographs presented by Guinee \& Kilcawley (2017) of a low-fat cheddar cheese are very similar to that seen in Figure $2 \mathrm{~d}$, which describe the entire smooth surface as a casein network. These results are consistent with those found for the optimal conditions because a high protein content was added and is found in a freer form when compared to the control sample. Lucas et al. (2018) noted how the addition of spirulina in a snack also modified its microstructure in addition to changing the nutritional content of the product. As for the composition, the amount of protein is higher than the optimum (15.1\%) when compared to the control (13.4\%) as it increases its nutritional value. With respect to fat content, the control presented $12.53 \%$, whereas the optimum had $8.28 \%$. Therefore, the product with the powder mixture formulation has desirable nutritional characteristics

\subsection{Storage}

The shelf-life and behavior or tendency of the product properties over time is of great interest to guarantee their quality. The change in the product and crust hardness is shown in Figure 3. The optimum sample had higher hardness values, and both samples increased their crust and product
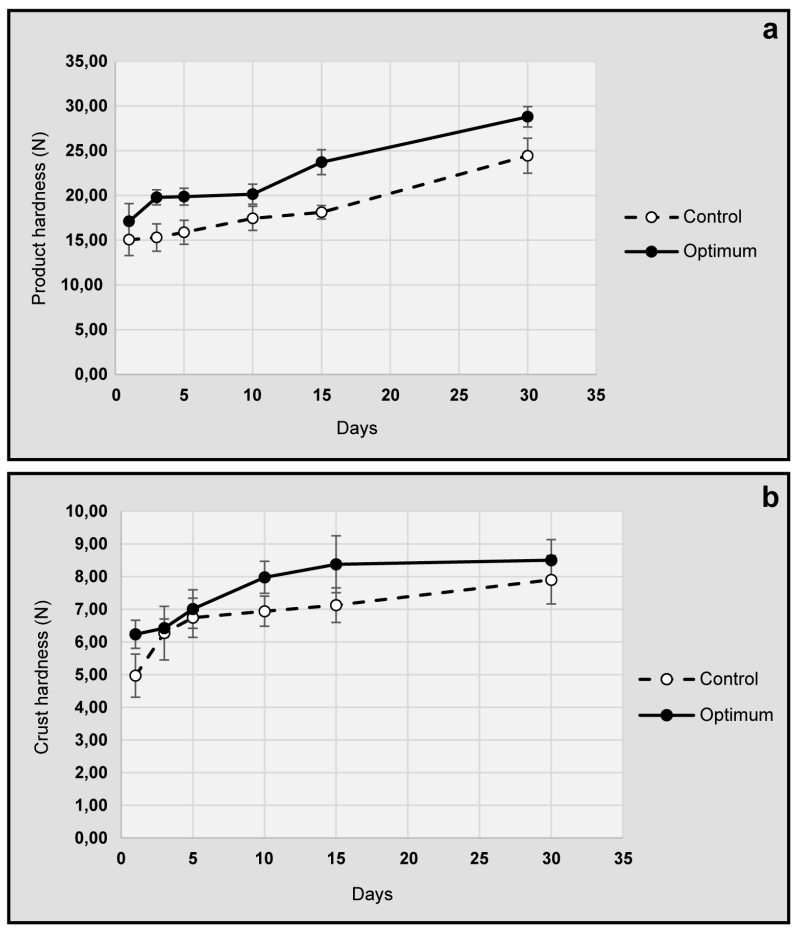

Figure 3. Product (a) and crust (b) hardness behavior in the control (empty circle) and the optimum (filled circle) samples over 30 days. hardness as the days went by; however, it is noteworthy that for the optimum, the hardness in the crust remains constant from day 15. Also, the product hardness of both samples (Figure 3) in the first days increased moderately, and from day 15 onwards the increase was considerable. Nhouchi et al. (2018) mentioned that fresher baked goods have lower hardness, as opposed to those that had been stored a certain number of days.

There are two approaches in sensory analysis, which consist of a hedonic evaluation based on a subjective panel and a descriptive approach based on a panel of experts (Nhouchi et al., 2018), both were performed in this study. In the acceptance test performed on day 15 of storage (Figure 4a), the panelists preferred the control sample with scores close to 8 in general acceptance, taste and texture, whereas the optimal snack resulted in a score of around 4 in those same characteristics. On day 30 (Figure $4 \mathrm{~b}$ ), the panelists preferred the optimum in terms of texture, this may be due to the hardness of this type of snacks tends to be stable over time. Whereas, the textural behavior presented by the control sample was increasing, resulting in a harder product compared to those produced in the first days, as evidenced in the texture results during storage time (Figure 3 ). After performing the QDA on the control sample on day 15 (Figure 4c), it can be evidenced that the descriptors of overall score, characteristic smell, characteristic flavor, and salty taste were perceived in greater intensity than the optimum condition; while cohesiveness, crispiness, adhesiveness, and characteristic color were similar for both samples. In addition, the judges identified astringent and residual sensation (bitter and metallic) in the optimum condition. On day 30, similar behaviors were evidenced in terms of color and crispiness, in addition to differences in the rest of properties, which were more intense in the control sample (Figure 4d). Over time, the score of important properties such as smell, taste, and crispiness decreased in both samples and, therefore, the overall score.

\section{Conclusions}

The optimal ring-shaped baked snack obtained after the different evaluated formulations presented values of $17.11 \mathrm{~N}, 6.23 \mathrm{~N}, 4.01 \mathrm{~mL} / \mathrm{g}$, and 0.41 for the properties of product hardness, hardness in the crust, specific volume, and porosity, respectively. These were different from the values presented by the traditionally prepared snack with fresh costeño cheese (control) with values of $15.06 \mathrm{~N}, 4.97$ $\mathrm{N}, 6.19 \mathrm{~mL} / \mathrm{g}$, and 0.56 , respectively; this is mainly due to the substitution of cheese and the absence of the proofing process in its manufacturing. However, it should be noted that the optimum product had higher protein content compared to the control; it is low in fat, being nutritionally better and giving it an added value that could influence the preference of consumers looking for products with higher nutritional value. With regard to sensory attributes, such as characteristic flavor and smell, they should be improved to ensure consumer acceptance. 

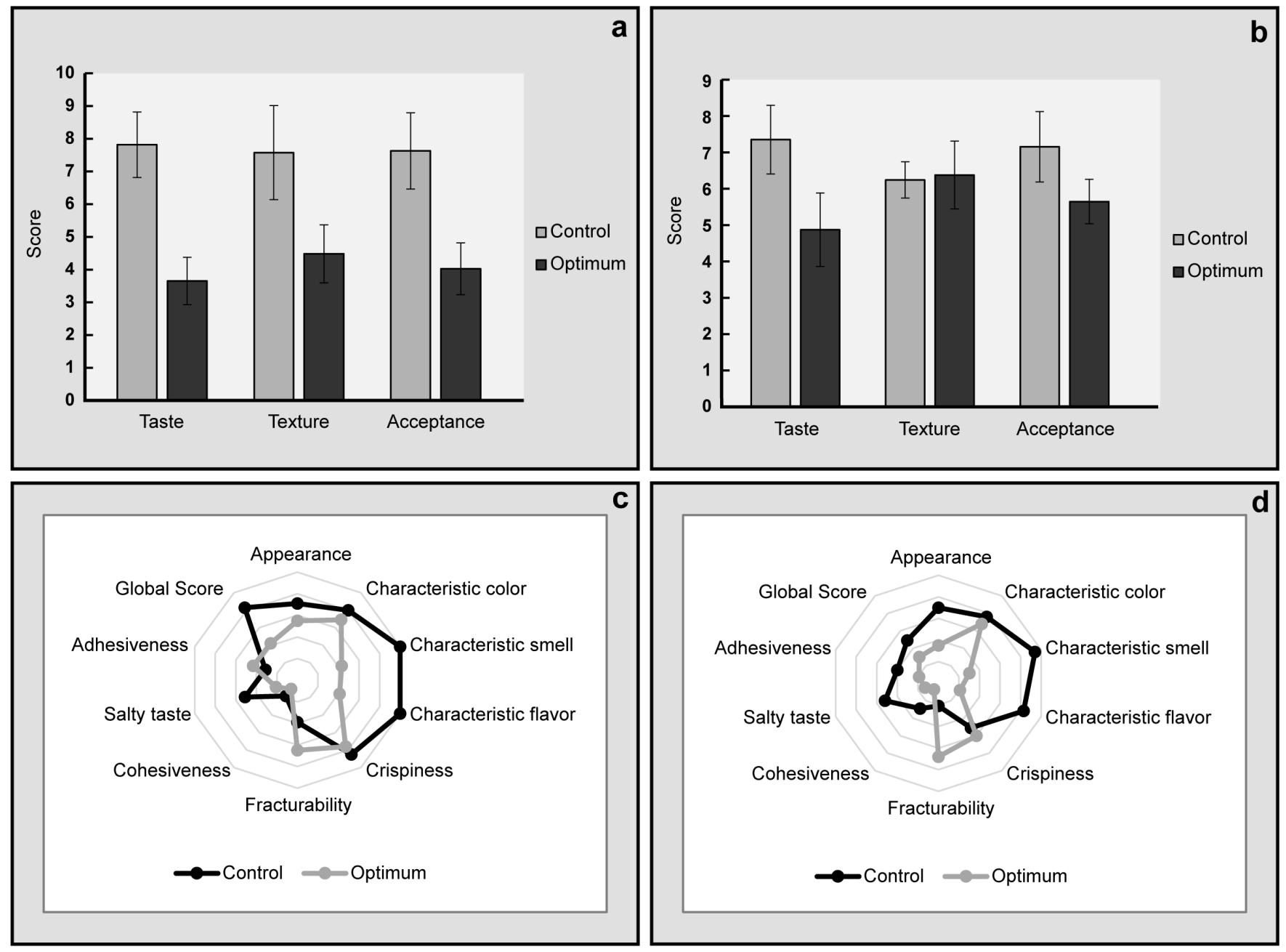

Figure 4. Sensory characteristics of the control and the optimum condition on day 15 (a) and 30 (b). Error bars are SE of mean values. Intensities of QDA sensory descriptors for control and optimal samples on day 15 (c) and 30 (d).

\section{References}

Arimi, J. M., Duggan, E., O’Riordan, E. D., O’Sullivan, M., \& Lyng, J. G. (2008). Microwave expansion of imitation cheese containing resistant starch. Journal of Food Engineering, 88(2), 254-262. http://dx.doi.org/10.1016/j.jfoodeng.2008.02.021.

Arimi, J. M., Duggan, E., O’Sullivan, M., Lyng, J. G., \& O’Riordan, E. D. (2012). Crispiness of a microwave-expanded imitation cheese: mechanical, acoustic and sensory evaluation. Journal of Food Engineering, 108(3), 403-409. http://dx.doi.org/10.1016/j.jfoodeng.2011.09.008.

Association of Official Analytical Chemists - AOAC. (2005). International Official Methods of Analysis (18th ed., Methods 981.12, 945.15, 945.16, 992.23, 32.10). Maryland: AOAC International.

Chaiyakul, S., Jangchud, K., Jangchud, A., Wuttijumnong, P., \& Winger, R. (2009). Effect of extrusion conditions on physical and chemical properties of high protein glutinous rice-based snack. Lebensmittel-Wissenschaft + Technologie, 42(3), 781-787. http://dx.doi.org/10.1016/j.lwt.2008.09.011.

Chang, H. C., \& Chen, H. H. (2013). Association between textural profiles and surface electromyographic (SEMG) behaviors of microwavable cassava cuttlefish crackers with various expansion ratios. Food Research International, 53(1), 334-341. http://dx.doi.org/10.1016/j.foodres.2013.04.015.
Díaz, A., Dini, C., Viña, S. Z., \& García, M. A. (2019). Fermentation and drying effects on bread-making potential of sour cassava and ahipa starches. Food Research International, 116, 620-627. http://dx.doi.org/10.1016/j.foodres.2018.08.081. PMid:30716988.

Fiorda, F. A., Soares, M. S. Jr., Silva, F. A., de Moura, C. M. A., \& Grossmann, M. V.E. (2015). Physical quality of snacks and technological properties of pre-gelatinized flours formulated with cassava starch and dehydrated cassava bagasse as a function of extrusion variables. Lebensmittel-Wissenschaft + Technologie, 62(2), 1112-1119. http://dx.doi.org/10.1016/j.lwt.2015.02.030.

Guinee, T. P. K., \& Kilcawley, N. (2017). Ingredient cheese and cheesebased ingredients. In: P. L. H. McSweeney, P. F. Fox, P. D. Cotte and D. W. Everett (Eds.), Cheese: chemistry, physics and microbiology (Chap. 29, pp. 715-755). $4^{\text {th }}$ edn. Oxford: Academic Press. http://dx.doi.org/10.1016/B978-0-12-417012-4.00029-6.

Hess, J. M., \& Slavin, J. L. (2018). The benefits of defining "snacks". Physiology \& Behavior, 193(Pt B), 284-287. http://dx.doi.org/10.1016/j.physbeh.2018.04.019. PMid:29678598.

Hosseini, M., Habibi Najafi, M. B., \& Mohebbi, M. (2014). Modification in the functional properties of sodium caseinate-based imitation cheese through use of whey protein and stabilizer. Journal of Agricultural Science and Technology, 16(6), 1313-1324. Retrieved from http://jast.modares.ac.ir/article-23-3239-en.html 
Instituto Colombiano de Normas Técnicas y Certificación - ICONTEC. (1996). Norma Técnica Colombiana (NTC) 3932: análisis sensorial. identificación y selección de descriptores para establecer un perfil sensorial por una aproximación multidimensional. Bogotá, Colombia: ICONTEC.

Jiang, H., Hettiararchchy, N. S., \& Horax, R. (2019). Quality and estimated glycemic profile of baked protein-enriched corn chips. Journal of Food Science and Technology, 56(6), 2855-2862. http://dx.doi.org/10.1007/s13197-019-03717-6. PMid:31205341.

Johnson, G. H., \& Anderson, G. H. (2010). Snacking definitions: impact on interpretation of the literature and dietary recommendations. Critical Reviews in Food Science and Nutrition, 50(9), 848-871. http://dx.doi.org/10.1080/10408390903572479. PMid:20924867.

Kahlon, T. S., Avena-Bustillos, R. J., \& Chiu, M. C. M. (2017). Sensory evaluation of gluten-free quinoa whole grain snacks. Heliyon, 3(1), e00213. PMid:28054034.

Kiziloz, M. B., Cumhur, O., \& Kilic, M. (2009). Development of the structure of an imitation cheese with low protein content. Food Hydrocolloids, 23(6), 1596-1601. http://dx.doi.org/10.1016/j.foodhyd.2008.11.006.

Lucas, B. F., Morais, M. G., Santos, T. D., \& Costa, J. A. V. (2018). Spirulina for snack enrichment: Nutritional, physical and sensory evaluations. Lebensmittel-Wissenschaft + Technologie, 90, 270-276. http://dx.doi.org/10.1016/j.lwt.2017.12.032.

Masotti, F., Cattaneo, S., Stuknyte, M., \& De Noni, I. (2018). Status and developments in analogue cheese formulations and functionalities. Trends in Food Science \& Technology, 74, 158-169. http://dx.doi.org/10.1016/j.tifs.2018.02.016.

Mazumder, P., Roopa, B. S., \& Bhattacharya, S. (2007). Textural attributes of a model snack food at different moisture contents. Journal of Food Engineering, 79(2), 511-516. http://dx.doi.org/10.1016/j.jfoodeng.2006.02.011.

Mesa, E., Manjarres-Pinzon, K., \& Rodriguez-Sandoval, E. (2019). Gluten-free cheese bread from frozen dough: effect of modified cassava starch. Food Science and Technology, 39(Suppl. 2), 654-661. http://dx.doi.org/10.1590/fst.30118.

Moorthy, S. N., Sajeev, M. S., \& Anish, R. J. (2018). Functionality of tuber starches. In M. Malin Sjöö \& L. Nilsson (Eds.), Starch in food: structure, function and applications (Chap. 11, pp. 421-508, 2nd ed.). Duxford: Woodhead Publishing Series in Food Science, Technology and Nutrition. http://dx.doi.org/10.1016/B978-0-08100868-3.00011-1.

Mudgil, D., Barak, S., \& Khatkar, B. S. (2016). Optimization of bread firmness, specific loaf volume and sensory acceptability of bread with soluble fiber and different water levels. Journal of Cereal Science, 70, 186-191. http://dx.doi.org/10.1016/j.jcs.2016.06.009.

Nhouchi, Z., Botosoa, E. P., \& Karoui, R. (2018). Critical assessment of formulation, processing and storage conditions on the quality of alveolar baked products determined by different analytical techniques: a review. Trends in Food Science \& Technology, 81, 159-171. http://dx.doi.org/10.1016/j.tifs.2018.09.014.

Oginni, O. C., Sobukola, O. P., Henshaw, F. O. W., Afolabi, A. O., \& Munoz, L. (2015). Effect of starch gelatinization and vacuum frying conditions on structure development and associated quality attributes of cassava-gluten based snack. Food Structure, 3, 12-20. http://dx.doi.org/10.1016/j.foostr.2014.12.001.
Otero-Guzmán, N. C., Rodríguez-Sandoval, E., \& Tabares-Londoño, J. A. (2020). Influence of different types of baking powder on quality properties of muffins. Revista DYNA, 87(214), 9-16. http://dx.doi.org/10.15446/dyna.v87n214.83549.

Ovaskainen, M. L., Reinivuo, H., Tapanainen, H., Hannila, M. L., Korhonen, T., \& Pakkala, H. (2006). Snacks as an element of energy intake and food consumption. European Journal of Clinical Nutrition, 60(4), 494-501. http://dx.doi.org/10.1038/sj.ejcn.1602343. PMid:16319836.

Özer, E. A., İbanoğlu, Ş., Ainsworth, P., \& Yağmur, C. (2004). Expansion characteristics of a nutritious extruded snack food using response surface methodology. European Food Research and Technology, 218(5), 474-479. http://dx.doi.org/10.1007/s00217-004-0884-7.

Paula, A. M., \& Conti-Silva, A. C. (2014). Texture profile and correlation between sensory and instrumental analyses on extruded snacks. Journal of Food Engineering, 121, 9-14. http://dx.doi.org/10.1016/j.jfoodeng.2013.08.007.

Philipp, C., Oey, I., Silcock, P., Beck, S. M., \& Buckow, R. (2017). Impact of protein content on physical and microstructural properties of extruded rice starch-pea protein snacks. Journal of Food Engineering, 212, 165-173. http://dx.doi.org/10.1016/j.jfoodeng.2017.05.024.

Pimentel, T. C., Gomes da Cruz, A., \& Deliza, R. (2016). Sensory evaluation: sensory rating and scoring methods. In B. Caballero, P. M. Finglas \& F. Toldra (Eds.), Encyclopedia of food and health (pp. 744-749, 1st ed.). Oxford: Academic Press. http://dx.doi.org/10.1016/B978-0-12-384947-2.00617-6

Quisca, R. P., Morán, J. V., Galloza, G. G., Arias, J. V. B., Montoya, E. N., Urquizo, F. L., Ramírez, M. E. R., Yacchi, T. A., \& Chávez, T. T. (2019). Development of a preservative for white fresh cheese from the addition of Peruvian Tara gum Caesalpinia spinosa. Food Science and Technology, 39(1), 210-215. http://dx.doi.org/10.1590/fst.00418.

Rodriguez-Sandoval, E., Cortes-Rodriguez, M., \& Manjarres-Pinzon, K. (2015). Effect of hydrocolloids on the pasting profiles of tapioca starch mixtures and the baking properties of gluten-free cheese bread. Journal of Food Processing and Preservation, 39(6), 1672-1681. http://dx.doi.org/10.1111/jfpp.12398.

Saeleaw, M., \& Schleining, G. (2011). Effect of frying parameters on crispiness and sound emission of cassava crackers. Journal of Food Engineering, 103(3), 229-236. http://dx.doi.org/10.1016/j.jfoodeng.2010.10.010.

Serpa, J. G., Pérez, T. I., \& Hernández, E. J. (2016). Effect of pasteurization and lactic acid bacteria on physicochemical, microbiological and sensorial characteristics of costeño cheese. Revista Facultad Nacional de Agronomía, 69(2), 8007-8014. http://dx.doi.org/10.15446/rfna.v69n2.59145.

Sharma, V., \& Bhardwaj, A. (2019). Scanning Electron Microscopy (SEM) in food quality evaluation. In J. Zhong \& X. Wang (Eds.), Evaluation technologies for food quality (Chap. 29, pp. 743-761, 1st ed., Series in Food Science, Technology and Nutrition). Duxford: Woodhead Publishing. http://dx.doi.org/10.1016/B978-0-12-814217-2.00029-9

Tadjine, D., Boudalia, S., Bousbia, A., Khelifa, R., Mebirouk Boudechiche, L., Tadjine, A., \& Chemmam, M. (2020). Pasteurization effects on yield and physicochemical parameters of cheese in cow and goat milk. Food Science and Technology, 40(3), 580-587. http://dx.doi.org/10.1590/fst.13119.

Tran, T., Da, G. M., Moreno-Santander, A., Vélez-Hernández, G. A., Giraldo-Toro, A., Piyachomkwan, K., Sriroth, K., \& Dufour, D. (2015). A comparison of energy use, water use and carbon footprint of cassava starch production in Thailand, Vietnam and Colombia. Resources, Conservation and Recycling, 100, 31-40. http://dx.doi.org/10.1016/j.resconrec.2015.04.007. 